\title{
Culture of horse oocytes in vitro
}

\author{
J. Fulka, Jr and A. Okolski* \\ Research Institute of Animal Production, 25161 Uhrinèves, Prague 10, Czechoslovakia and \\ *Institute of Applied Animal Physiology, Academy of Agriculture Al. Mickiewicza 24-28, \\ Krakow, Poland
}

\begin{abstract}
Summary. Oocytes were removed from follicles $5-30 \mathrm{~mm}$ in diameter. The germinal vesicle was present in $69.6 \%(23 / 33)$ of the oocytes at the start of culture, but after $20-24$ and $40 \mathrm{~h} 70 \cdot 5 \%(12 / 17)$ and $68 \cdot 2 \%(43 / 63)$ of the oocytes were in metaphase I and metaphase II with first polar body extruded, respectively.
\end{abstract}

\section{Introduction}

Pincus \& Enzmann (1935) were the first to observe that rabbit oocytes resume meiosis when cultured outside the follicle. Since that time oocyte maturation has been investigated in many mammals, including farm animals (for review, see Thibault, 1977). However, there is limited knowledge of oocyte maturation in horses and the present study of horse oocytes in vitro was therefore undertaken.

\section{Materials and Methods}

Oocytes were aspirated from antral follicles of different sizes $(5-30 \mathrm{~mm})$ in the ovaries of slaughtered mares. The ovaries of 8-12 mares were usually taken at each collection. Oocytes in the follicular fluid were transported to the laboratory in a container at $30^{\circ} \mathrm{C}$. There they were removed from the follicular fluid under a stereomicroscope and only those (80) with a compact cumulus were used. The oocytes were washed 3 times in medium and cultured in $0.1 \mathrm{ml}$ medium under paraffin oil in $5 \% \mathrm{CO}_{2}$ in air at $37.5^{\circ} \mathrm{C}$. The composition of medium was that described by Pavlok \& McLaren (1972) and modified by Motlik \& Fulka (1974).

Two culture intervals, 20-24 h and $40 \mathrm{~h}$, were chosen, and 33 oocytes served as a control of nuclear stage at the start of culture. The cumulus cells were removed by gently sucking the oocytes through a narrow pipette and the oocytes were mounted, fixed in acetic alcohol (1:3 $\mathrm{v} / \mathrm{v})$, stained with orcein and evaluated under a phase-contrast microscope.

\section{Results}

Approximately 30 oocytes were obtained in each collection, i.e. 3-5 oocytes per mare. Most control oocytes (Table 1) were at the germinal vesicle stage with a clearly visible nucleolus, finely granulated nucleoplasm and distinct nuclear membrane. Chromatin, intensively stained in a horseshoe pattern, was detected at the periphery of the nucleolus (PI. 1, Fig. 1), or as an orcein-positive material distributed in the nucleoplasm. 
Table 1. Maturation of horse oocytes in culture

\begin{tabular}{cccccc}
\hline \multirow{2}{*}{$\begin{array}{c}\text { Duration } \\
\text { of culture } \\
(\mathrm{h})\end{array}$} & $\begin{array}{c}\text { No. of } \\
\text { oocytes } \\
\text { cultured }\end{array}$ & $\begin{array}{c}\text { Germinal } \\
\text { vesicle }\end{array}$ & Metaphase I & $\begin{array}{c}\text { Metaphase Il + } \\
\text { 1st polar body }\end{array}$ & Abnormal \\
\hline 0 & 33 & $23(69 \cdot 6 \%)$ & 5 & 0 & 5 \\
$20-24$ & 17 & 0 & $12(70.5 \%)$ & 2 & 3 \\
40 & 63 & 0 & 4 & $43(68.2 \%)$ & 16 \\
\hline
\end{tabular}

After culture for 20-24 or $40 \mathrm{~h}$, more oocytes were in metaphase I (Pl. 1, Fig. 2) and metaphase II (PI. 1, Figs 3 and 4), respectively. Oocytes for which the stage of development was difficult to identify were classed as abnormal.

\section{Discussion}

The results presented here show that horse oocytes need a relatively long period for their nuclear maturation in vitro. In most mammalian species the sequence of chromosomal changes continues more rapidly, but pig (Motlik, 1972), human (Jagiello, Ducayen, Miller, Graffeo \& Fang, 1975) and sheep (Quirke \& Gordon, 1971) oocytes also have a longer maturation. The use of more oocytes for detailed studies would be desirable but in horses this possibility is limited by the low number of antral follicles in the ovaries, particularly in the autumn when these experiments were carried out and the sexual activity of mares is very low (Bielański, 1972; Driancourt, 1979).

The relatively large numbers of oocytes classified as abnormal are probably due to the derivation of the oocytes from atretic follicles, in spite of the selection before culture and the use of oocytes with cumulus cells. McGaughey, Montgomery \& Richter (1979) showed that oocytes from pig follicles at different stages of atresia resume but do not complete meiosis.

Further studies of horse oocyte maturation should also consider the controversy about development in the preovulatory follicles; Hamilton \& Day (1945) claimed that dictyate oocytes are normally ovulated and that maturation is completed in the oviduct, while Van Niekerk \& Gerneke (1966) consider that metaphase II occurs shortly before ovulation. According to Webel, Franklin, Harland \& Dziuk (1977) both observations are correct. These authors found freshly ovulated oocytes at metaphase II in pony mares and also oocytes which had not yet completed maturation. These oocytes were examined $42-52 \mathrm{~h}$ after hCG injection. It means that the time necessary for maturation in vivo and in vitro, observed in our experiments, is very similar.

J. Fulka thanks Professor W. Bielański and Dr M. Tischner who made it possible to carry out this study and provided valuable discussion. The investigation was supported by grant No. MR 2.10 from the Agriculture Academy in Wrockaw, Poland.

\section{References}

Bielański, W. (1972) Rozród zwierzat, 2nd edn. Państwowe Wydawnictwo Rolnicze i Lesne, Warszawa.

Driancourt, M.A. (1979) Follicular kinetics in the mare ovary. Annls Biol. anim. Biochim. Biophys. 19, 1443-1453.

Hamilton, W.J. \& Day, F.T. (1945) Cleavage stages of the ova of the horse, with notes on ovulation. J. Anat. $79,127-132$.

Jagiello, G., Ducayen, M., Miller, W., Graffeo, J. \& Fang, J.S. (1975) Stimulation and inhibition with LH and other hormones of female mammalian meiosis in vitro. J. Reprod. Fert. 43, 9-22.

McGaughey, R.W., Montgomery, D.H. \& Richter, J.D. 


\section{PLATE 1}
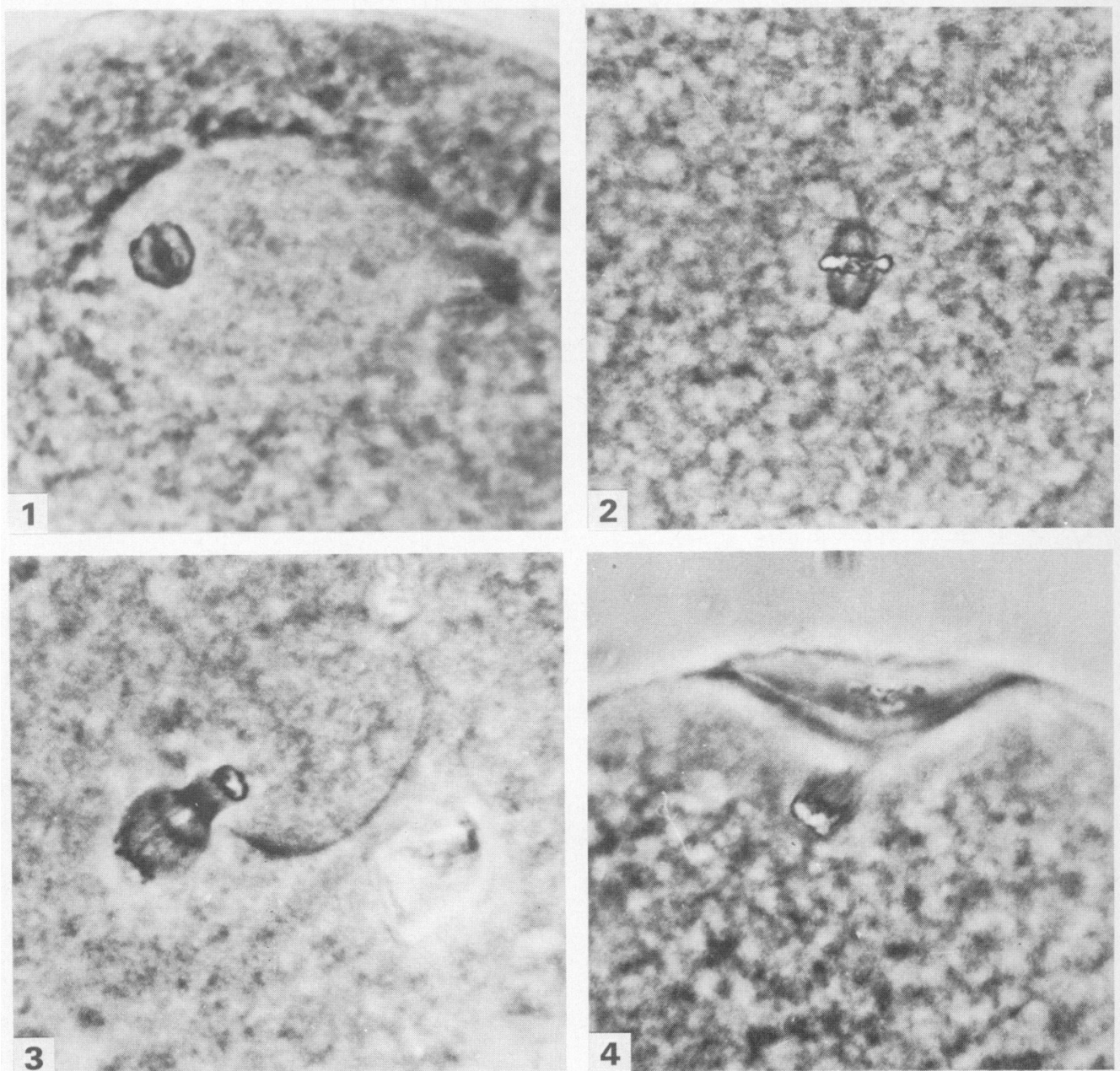

Fig. 1. The nucleus of the oocyte at the start of culture. The nucleolus with condensed chromatin is visible. The nucleoplasm is finely granulated and surrounded by a nuclear membrane. Phase contrast, $\times 1900$.

Fig. 2. Oocyte after $24 \mathrm{~h}$ of culture. The chromosomes are in metaphase l. Phase contrast, $\times 1900$.

Figs 3 and 4. Oocytes after $40 \mathrm{~h}$ of culture, showing formation of the first polar body. Phase contrast, $\times 1200$. 
(1979) Germinal vesicle configurations and patterns of polypeptide synthesis of porcine oocytes from antral follicles of different size, as related to their competency for spontaneous maturation. $J$. exp. Zool. 209, 239-254.

Motilik, J. (1972) Cultivation of pig oocytes in vitro. Folia biol., Praha 18, 345-352.

Motlik, J. \& Fulka, J. (1974) Fertilization of pig follicular oocytes cultivated in vitro. J. Reprod. Fert, 36, 235-237.

Pavlok, A. \& McLaren, A. (1972) The role of cumulus cells and the zona pellucida in fertilization of mouse eggs in vitro. J. Reprod. Fert. 29, 91-97.

Pincus, G. \& Enzmann, E.V. (1935) The comparative behaviour of mammalian eggs in vivo and in vitro. 1 . The activation of ovarian eggs. J. exp. Med. 62, $665-675$.
Quirke, J.F. \& Gordon, I. (1971) Culture and fertilization of sheep ovarian oocytes. I. Effect of culture medium on resumption of meiosis. J. agric. Sci., Camb. 76, 369-372.

Thibault, C. (1977) Are follicular maturation and oocyte maturation independent processes? J. Reprod. Fert. $51,1-15$.

Van Niekerk, C.H. \& Gerneke, W.H. (1966) Persistence and parthenogenetic cleavage of tubal ova in mare. Onderstepoort J. vet. Res. 32, 195-232.

Webel, S.K., Franklin, V., Harland, B. \& Dziuk, P.J. (1977) Fertility, ovulation and maturation of eggs in mares injected with hCG. J. Reprod. Fert. 51, 337-341.

Received 16 June 1980 